\title{
Milk peptides with physiological activities. II. Opioid and immunostimulating peptides derived from milk proteins
}

\author{
M Coste, D Tomé * \\ INRA, Laboratoire de Nutrition Humaine et Physiologie Intestinale, UER des Sciences \\ Pharmaceutiques et Biologiques, 4, avenue de l'Observatoire, 75006 Paris, France
}

\begin{abstract}
Summary - The presence of peptides with opioid (exorphins) or immunomodulating activity has been demonstrated in the sequence of milk proteins. These activities were detected using in vitro technics. Active sequences are particularly present in the sequence of caseins. Their physiological significance remains unclear. The in vivo expression of these activities is first dependent on the existence of mechanisms that modulate the degradation and absorption of the active compounds, and that permit their transport to specific receptors. Opioid receptors are present at different levels in the gut or in the central nervous system. The action of exorphins is similar to that of other endogenous and exogenous opiates. Other peptides have been shown to act on macrophage and lymphocyte functions. The protective effect of these natural compounds constitutes an interesting potential application.
\end{abstract}

food protein / peptide / opiate / immunomodulation

Résumé - Les peptides du lait à activités physiologiques : activité morphinomimétique et immunostimulante. Divers peptides possédant des activités opiacée (exorphines) ou immunostimulantes, ont été mis en évidence dans la séquence des protéines de lait. Ces activités ont été détectées principalement à l'aide de tests in vitro, utilisant des extraits d'organes, des cellules isolées ou en culture, des organes isolés. Les caséines du lait sont particulièrement riches en séquences actives. La signification physiologique de ces composés est encore mal comprise. La manifestation de ces activités nécessite en premier lieu l'existence de systèmes contrôlant leur dégradation et leur absorption, et assurant leur accès jusqu'à leurs cibles dans l'organisme, à un niveau digestif ou systémique. Des récepteurs réagissant avec les exorphines ont été trouvés aussi bien au niveau digestif, qu'au niveau du système nerveux central. Les effets observés sont analogues à ceux des autres opiacés endogènes ou exogènes. D'autres peptides agissent sur la fonction des macrophages, sur les lymphocytes $B$, sur les lymphocytes $T$. Le rôle "protecteur" de ces molécules d'origine naturelle est une voie d'étude prometteuse.

protéine alimentaire / peptide / opiacé / immunomodulation

\footnotetext{
${ }^{*}$ Correspondence and reprints
} 


\section{INTRODUCTION}

A major role of milk proteins is to supply amino acids and nitrogen to the young mammal. Milk proteins also constitute an important part of dietary proteins for the adult. However, these proteins should not only be considered as nutrients for they probably have a physiological role as well. This idea originates from the observations that some dietary proteins serve as a source of biologically active peptides. This aspect of milk proteins has been extensively studied for the last $10 \mathrm{yr}$, and a number of peptides with various activities have been found in the amino acid sequence of these proteins, including opiate activity, immunomodulating properties, enzyme inhibitors, ion transport properties, and hormone modulation effect. The first biologically active peptides found in milk were the opioid peptides, followed by the discovery of immunomodulating peptides. Two important steps in these studies include: 1), the identification of the active components of the protein; and 2), the understanding of their potential physiological function. Most often, these questions are answered through in vitro investigations and the physiological functions of the peptides remains to be established in vivo. We will review the existing literature in this area, with special reference to the biological systems studied.

\section{IDENTIFICATION OF OPIOID AND IMMUNOMODULATING COMPONENTS}

\section{Opioid activities}

Opiate activities of milk protein derived peptides have been measured by opiate receptor binding assays, in isolated organ preparation (longitudinal muscle myenteric plexus preparation of the guinea pig ileum, mouse vas deferens, rat vas deferens) or in the intact animal after intracerebroventricular injection (Zioudriou et al, 1979; Brantl et al, 1981, 1982; Liebman et al, 1986).

Several types of opiate agonistic peptides have been characterized and exert naloxone inhibitable opioid activities. The first opioid peptides described were in the $60-70$ fragment of bovine $\beta$-casein (Brantl et al, 1979). This fragment and the Cterminally shortened derived peptides are called $\beta$-casomorphins, and characterized by the $\mathrm{N}$-terminal sequence Tyr-Pro-PhePro. Similar peptides, called human- $\beta$ casomorphins, have been found in the 41 $44,51-58$, and 59-63 fragments of human $\beta$-casein (Brantl, 1985; Koch et al, 1985). An $\alpha$-casein exorphin was identified as the 90-96 fragment of bovine $\alpha$-casein (Loukas et al, 1983). Moreover, $\beta$-casomorphin analogs have been prepared by C-terminal amidation and amino acid substitution, in order to increase opioid potency and to modify opiate receptor specificity (Brantl et al, 1981, 1982; Liebman et al, 1986).

\section{Macrophage functions}

The macrophage response to peptides derived from human and bovine caseins has been studied using different techniques including phagocytosis of opsonized sheep red blood cells by resident peritoneal mouse macrophages, secretion of hemoIytic antibodies by spleen cells from mice which have been immunized in vivo by sheep red blood cells, and protection of mice against Klebsiella pneumoniae infection (Jollès et al, 1981, 1982).

A tryptic digest of delipidated human casein contains an immunomodulatory fraction with a molecular weight of $\approx 2000$ that has been demonstrated to stimulate phagocytosis by macrophages from B6D2F1 mice, and hemolytic antibody secretion by spleen cells of CBA mice (Jollès et al, 1981, 1982). One of these peptides 
has been identified as a hexapeptide ( ValGlu-Pro-lle-Pro-Tyr) which corresponds to the 54-59 fragment of human $\beta$-casein. More-over, intravenous injection (0.5-1.0 $\mathrm{mg} / \mathrm{kg}$ ) of this hexapeptide has been shown to enhance the resistance of mice to infection with Klebsiella pneumoniae. The authors argued that macrophages were the main target of activity because the stimulatory effect of antibody secretion was not exerted by the purified peptide (Parker et al, 1984). Another hexapeptide (Pro-Gly-Pro-lle-Pro-Asn) from bovine $\beta$ casein is localized in the same region (fragment 63-68), and also stimulated phagocytosis (Mig-liore-Samour and Jollès, 1988).

Berthou et al (1987) identified 2 immunostimulating tripeptides. One of these tripeptides, the human casein fragment GlyLeu-Phe, had an effect on phagocytosis in vitro in the same range of concentrations tested for the hexapeptides. This peptide protected against $K$ pneumoniae infections by intravenous or subcutaneous administration. Interestingly, in some assays, the protection was more pronounced at doses of $1 \mathrm{mg} / \mathrm{kg}$ than at $5 \mathrm{mg} / \mathrm{kg}$.

The hexapeptide and Gly-Leu-Phe fragment $(1 \mu \mathrm{M})$ from human casein stimulated the binding and the phagocytosis of human senescent red blood cells by monocyte/ macrophage cells to the same magnitude as the immunomodulatory lauroyltetrapeptide (Gattegno et al, 1988). In contrast, the bovine $\beta$-casein fragment 191-193 LeuLeu-Tyr increased phagocytosis and slightly increased antibody secretion but failed to exert an in vivo protection in mice (Berthou et al, 1987).

\section{B-cell functions}

B-lymphocyte functions have been compared between both breast and cow's milk fed infants. Juto et al (1982) observed that peripheral blood lymphocytes had low re- sponsiveness when they were stimulated with suboptimal doses of mitogen. A suppressive effect on lymphocyte proliferation was also observed with milk (Ogra and Ogra, 1978). However, stimulatory activities have also been described. Juto (1985) was the first author to describe a soluble activity in milk that affected B-cell function. $\mathrm{He}$ observed that human colostrum and mature milks enhanced the mice spleen cell proliferation response to lipopolysaccharide (LPS). Antibody secretion in cell culture supernatants was also stimulated. In contrast, formula milk failed to potentiate $B$-cell response. The author argued that interleukin I, a cytokine produced by macrophages and present in various biological fluids such as milk, was not responsible for the observed stimulation because the activity of the cytokine is heat-sensitive at $56^{\circ} \mathrm{C}$.

More recently, Julius et al (1988) studied mouse B-cell function with a purified proline-rich protein preparation (PRPP) from sheep colostrum. These investigators cultured spleen resting B-cells with PRPP, and analyzed a panel of activation events at various time cultures. During these studies they observed that membrane depolarization, proliferative responses and Igsecreting cells were stimulated by PRPP. Unlike the case of LPS, Ig expression by $B$-cells remained unchanged. With neonatal splenocytes, mitogenic and differentiation effects were observed. IgM production was stimulated; however, unlike LPS, the PRPP fraction did not induce a switch in Bcells. Moreover, for low cell culture densities, PRPP was more mitogenic than LPS. These results suggest that the PRPP effect may occur by alternative activation mechanisms.

\section{T-cell functions}

The influence of milk proteins on human $T$ cell function was recently studied by Min- 
cheva-Nilsson et al (1990). Investigating the effect of milk proteins on a leucoagglutinin-induced T-cell proliferation, the authors observed a dual effect of the milk proteins. Concentrations of colostral proteins $\geq 10 \mu \mathrm{g} / \mathrm{ml}$ exerted a dosedependent inhibition of proliferation, while lower concentration of colostral and late milk proteins had an amplifying effect. The inhibitory effect was recovered after protein fractionation and was also found to strongly suppress an anti-CD3-induced proliferation and a one-way mixed lymphocyte reaction. The protein fraction exerting this inhibition was identified as a glycoprotein (con A eluted). The inhibition did not appear to be mediated through cytotoxicity in lymphocytes. Interestingly, milk proteins in the absence of a T-cell stimulant had no effect on proliferation, suggesting that these activities occurred only on activated T-cells.

Results from our laboratory showed that a C-terminal peptides derived from bovine $\beta$-casein enhanced an antigen driven $T$ cell proliferation while the native protein failed to exert this effect (unpublished data).

\section{PHYSIOLOGICAL ROLE OF OPIOID AND IMMUNOMODULATING PEPTIDES}

\section{Appearance of bioactive sequences}

The investigation of the mechanisms and conditions responsible for the expression of the physiological role of biological substances such as peptides implies the elucidation of their metabolism, since peptides can be rapidly degraded in vivo. Different types of experiments have been performed to determine whether active peptides are released from proteins and $a b$ sorbed after ingestion of milk including in vitro digestion studies, or small intestinal content and blood analysis after milk or peptide ingestion both in the animal and man.

In the case of $\beta$-casomorphins, it was shown that these peptides or larger precursors are cleaved from $\beta$-casein by digestion in vitro and in vivo, and are resistant to gastric and pancreatic proteolytic enzymes. The presence of $\beta$-casomorphins and $\beta$-casomorphin immunoreactive material has been demonstrated in the intestine of animals and humans after milk ingestion (Svedberg et al, 1985; Umbach et al, 1985; Meisel, 1986). However, enzyme systems with the capacity to hydrolyze these peptides have been detected in the brush border membrane of intestinal cells (Tomé et al, 1987; Mahé et al, 1989; Mahé et al, 1990), in the plasma (Kreil et al, 1983) and in the brain and liver (Stark et al, 1987). Moreover, intact peptide absorption has not been detected in adult animals and humans (Teschemacher et al, 1986), whereas $\beta$-casomorphin immunoreactive material has been detected in the plasma of newborn animals (Singh et al, 1989; Read ef al, 1990). Therefore, it seems likely that in the adult, under physiological conditions, peptides containing $\beta$-casomorphin sequences contact the luminal surface of the intestine, but are rapidly hydrolyzed during their absorption or after their transfer to the blood. In the newborn, absorption of the intact peptides implies a modulation of the peptide system of degradation. An alternative possibility is the absorption of larger precursors (Singh et al, 1989).

Interestingly, both immunostimulatory peptides and $\beta$-casomorphins have been located in parts of the sequence of $\beta$ caseins. Fiat and Jollès (1989) suggested that a "strategic zone" containing biologically active peptides may be considered in the fragment $51-63$ of human and $60-70$ of bovine $\beta$-caseins. 


\section{Potential physiological actions of the peptides}

As previously stated, it is probable that under physiological conditions, peptides containing $\beta$-casomorphin sequences cleaved from $\beta$-casein, and contact the luminal surface of the intestine. The existence of a $\beta$ casomorphin-receptor interaction at the brush-border membrane with subsequent effects on nutrient absorption has been proposed (Ermish et al, 1989). Such an interaction, if it exists, is probably not an opiate-like action for no opioid receptor has been located on the brush-border membrane, nor has a direct opiate action on the luminal surface been demonstrated (Tomé et al, 1987). Other studies have demonstrated an interaction of $\beta$-casomorphins with opiate receptors located on the blood side of the intestinal epithelium with subsequent modification of electrolyte transport by an opiate neuromediated mechanism (Tomé et al, 1987; Ben Mansour et al, 1988; Mahé et al, 1989, 1990).

$\beta$-casomorphins exhibit various opiatelike activities similar to those of other endogenous and exogenous opiates. After intragastric administration of $\beta$-casomorphins in dogs, modulation of postprandial insulin, somatostatin, and pancreatic polypeptide release has been observed (Schusdziarra et al, 1983a,b,c). These peptides have also been shown to induce analgesia (Chang et al, 1982), depress cardiorespiratory function (Wei et al, 1980), and alter behavior (Panksepp et al, 1984), with possible effects on the development of the central nervous system of the newborn also (Voltera et al, 1986).

Immunomodulation by milk proteins and peptides has been investigated by a few authors. It is known that breast milk contains various biological substances such as immunoglobulins, enzymes and growth factors (Carpenter, 1980) which provide passive protection against infection in the infant. More recently, some authors argued that other protein and peptide components including both suppressive and enhancing factors may have regulatory properties on the development of the immune system such as the induction of immune tolerance and the prevention of hypersensitivities to food antigens. These substances have been found not only in human colostrum and late milk (Jollès et al, 1981, 1982; Mincheva-Nilsson et al, 1990), but also in sheep (Julius et al, 1988) and bovine (Berthou et al, 1987) milk.

\section{CONCLUSION}

Various data are currently available on the presence of peptides in milk with opiate and immunomodulating activity. At this time, their physiological significance and the degree to which they exert their effects is unknown. These active natural components of milk are probably of interest in pharmacological applications. For instance, the protective effect of some components may have practical applications.

\section{REFERENCES}

Ben Mansour A, Tomé D, Rautureau M, Bisalli A, Desjeux JF (1988) Luminal antisecretory effects of a $\beta$-casomorphin analogue on rabbit ileum treated with cholera toxin. Pediatr Res 24, 751-755

Berthou J, Migliore-Samour D, Lifchitz A, Delettré J, Floc'h F, Jollès P (1987) Immunostimulating properties and three-dimensional structure of two tripeptides from human and cow caseins. FEBS Lett 218, 55-58

Brantl V (1985) Novel opioid peptides derived from human $\beta$-casein: human $\beta$-casomorphins. Eur J Pharmacol 106, 213-214

Brantl V, Teschemacher H, Henschen A, Lottspeich F (1979) Novel opioid peptides de- 
rived from casein ( $\beta$-casomorphins), I. Isolation from bovine casein peptone. HoppeSeyler's Z Physiol Chem 360, 1211-1216

Brantl V, Teschmacher $H$, Bläsig J, Henschen A, Lottspeich $F$ (1981) Opioid activities of $\beta$ casomorphins. Life Sci 28, 1903-1909

Brantl V, Pfeiffer A, Herz A, Henschen A, Lottspeich $F$ (1982) Antinociceptive potencies of $\beta$-casomorphin analogs as compared to' their affinities towards $\mu$ and $\delta$ opiate receptor sites in brain and periphery. Peptides 3,793 797

Carpenter G (1980) Epidermal growth factor is a major growth promoting agent in human milk. Science 210, 198-199

Chang K, Cuatrecasas P, Wei E, Chang J (1982) Analgesic activity of intracerebroventricular administration of morphiceptin and $\beta$ casomorphins: correlation with the morphine ( $\mu$ ) receptor binding affinity. Life Sci 30 , 1547-1551

Ermish A, Brust P, Brandsch M (1989) $\beta$ casomorphins alter intestinal accumulation of L-leucine. Biochim Biophys Acta 982, 79-84

Fiat AM, Jollès $P$ (1989) Caseins of various origins and biologically active casein peptides and oligosaccharides: structural and physiological aspects. Mol Cell Biochem 87, 5-30

Gattegno L, Migliore-Samour D, Saffar L, Jollès $P$ (1988) Enhancement of phagocytic activity of human monocytic-macrophagic cells by immunostimulating peptides from human casein. Immunol Lett 18, 27-32

Jollès $\mathrm{P}$, Parker F, Floc'h F, Migliore D, Alliel P, Zerial A, Werner GH (1981-1982) Immunostimulating substances from human casein. J Immunopharmaco/ 3, 363-369

Juto $P$, Möller C, Engberg S, BjörKstén B (1982) Influence of type of feeding on lymphocyte function and development of infantile allergy. Clin Allergy 12, 409-416

Julius MH, Janusz M, Lisowski J (1988) Colostral protein that induces the growth and differenciation of resting $\beta$-lymphocytes. J Immunol 140, 1366-1371

Juto P (1985) Human milk stimulate B cell function. Arch Dis Child 60, 610-613

Koch G, Wiedemann K, Teschemacher H (1985) Opioid activities of human $\beta$ casomorphins. Naunym-Schmiedeberg's Arch Pharmacol 331, 351-354
Kreil G, Umbach M, Brantl V, Teschmacher H (1983) Studies on the enzymatic degradation of $\beta$-casomorphins. Life Sci 33, 137-140

Liebman C, Szucs M, Neubert K, Hartrodt B, Arold H, Barth A (1986) Opiate receptor binding affinities of some $D$-amino acid substituted $\beta$-casomorphin analogs. Peptides 7, 195199

Loukas S, Varoucha D, Zioudriou C, Streaty R (1983) Opioid activities and structures of $\alpha$ casein-derived exorphins. Biochemistry 22, 4567-4573

Mahé S, Tomé D, Dumontier AM, Desjeux JF (1989) Absorption of intact morphiceptin by diisopropylfluorophosphate-treated rabbit ileum. Peptides 10, 45-52

Mahé S, Dumontier AM, Tomé D (1990) Intestinal action and absorption of $\beta$-casomorphins. In: $\beta$-Casomorphins and Related Peptides (Nyberg F, Brantl V, eds) Fyris-Tryck AB, Uppsala, Sweden, 79-85

Meisel H (1986) Chemical characterization and opioid activity of an exorphin isolated from in vivo digests of casein. FEBS Lett 196, 223227

Migliore-Samour D, Jollès P (1988) Casein, a prohormone with an immunomodulating role for the newborn? Experientia 44, 188-193

Mincheva-Nilsson L, Hammarström ML, Juto P. Hammarström S (1990) Human milk contains proteins that stimulate and suppress $\mathrm{T}$ lymphocyte proliferation. Clin Exp Immunol 79, $463-469$

Ogra SS, Ogra PL (1978) Immunologic aspects of human colostrum and milk. J Pediatr 92, 550-555

Panksepp J, Normansell L, Siviy S, Rossy J, Zolovick A (1984) Casomorphins reduce separation distress in chicks. Peptides 5, 829831

Parker F, Migliore-Samour D, Floc'h S, Zerial A, Werner $G H$, Jollès $J$, Casaretto $M$, Zahn $H$, Jollès $P$ (1984) Immunostimulating hexapeptide from human casein: amino acid sequence, synthesis and biological properties. Eur J Biochem 145, 677-682

Read L, Lord A, Brantl V, Koch G (1990) Absorption of $\beta$-casomorphins from autoperfused lamb and piglet small intestine. Am $J$ Physiol 259 (Gastrointest Liver Physiol, 22) G443-G452 
Schusdziarra V, Schick A, Fuente A, Sprecht J, Klier M, Brantl V, Pfeiffer E (1983a) Effect of $\beta$-casomorphins and analogs on insulin release in dogs. Endocrinology 112, 885-889

Schusdziarra V, Schick A, Fuente A, Holland A, Brantl V, Pfeiffer E (1983b) Effect of $\beta$ casomorphin on somatostatin release in dogs. Endocrinology 112, 1948-1951

Schusdziarra V, Schick A, Holland A, Fuente A, Specht S, Maier V, Brantl V, Pfeiffer E (1983c) Effect of opiate-active substances on pancreatic polypeptide levels in dogs. Peptides 4, 205-210

Singh M, Rosen C, Chang K, Haddah G (1989) Plasma $\beta$-casomorphin-7 immunoreactive peptide increases after milk intake in newborn but not in adult dogs. Pediatr Res 26, 34-38

Stark H, Lössner B, Matties H (1987) Metabolism of $\beta$-casomorphin and its derivatives in rat brain and liver homogenates. Biomed Biochim Acta 10, 687-694

Svedberg J, De Haas J, Leimenstoll G, Paul F, Teschmacher H (1985) Demonstration of $\beta$ casomorphin immunoreactive materials in in vivo digests of bovine milk and in small intestine contents after bovine milk ingestion in adult humans. Peptides 6, 825-830
Teschmacher H, Umbach M, Hamel U, Praetorius K, Ahnert-Hilger G, Brantl V, Lottspeich F, Henschen A (1986) No evidence for the presence of $\beta$-casomorphins in human plasma after ingestion of cow's milk or milk products. $J$ Dairy Res 53, 135-138

Tomé D, Dumontier AM, Hautefeuille M, Desjeux JF (1987) Opiate activity and transepithelial passage of intact $\beta$-casomorphins in rabbit ileum. Am J Physiol 253 (Gastrointest Liver Physiol 16), G737-G744

Umbach $M$, Teschmacher $H$, Praetorius $K$, Hirschhäuser R, Bostedt $H$ (1985) Demonstration of a $\beta$-casomorphin immunoreactive material in the plasma of newborn calves after milk intake. Regul Peptides 12, 223-230

Voltera A, Restani P, Brunello N, Galli C, Racagni $G$ (1986) Interaction of $\beta$-casomorphin with multiple opioid receptors: in vitro and in vivo studies in the newborn rat brain. Dev Brain Res 30, 25-30

Wei E, Leo A, Chang J (1980) Cardiovascular effects of peptides related to the enkephalins and $\beta$-casomorphins. Life Sci 26, 1517-1522

Zioudriou C, Streaty R, Klee W (1979) Opioid peptides derived from food proteins: the exorphins. J Biol Chem 254, 2446-2449 